\title{
RAJANTEKOJA, KAIPAUSTA, KAPINAA
}

Käsillä oleva Lähikuvan teemanumero paneutuu kuulumisen monimuotoiseen tematiikkaan, joka avautuu paitsi poliittisen myös affektiivisen ja eettisen alueille.

Englanninkielisestä tutkimuksesta lainattu termi kuuluminen (belonging) voi sanakirjamerkityksessään viitata omistussuhteeseen tai tunteeseen, että kuuluu johonkin paikkaan, ryhmään tai yhteisöön: on jollain tavalla osa näitä, kuten ne ovat osa itseä. Suomen kielessä termi on kuitenkin paljon moniselitteisempi - se liittyy edellä mainittujen lisäksi kuulumisten kyselyyn, kuuloaistiin ja jonkin asian merkityksellisenä tai välttämättömänä pitämiseen. Vaikka tässä lehdessä kuuluminen ymmärretään erityisesti kiinnittymisenä ja juurten kasvattamisen (tai niistä irtautumisen: ei-kuulumisen) kokemuksena, sekä ohimennen myös omistajuutena, voi sanan muista suomen kielessä saamista merkityksistä ammentaa kiinnostavia ristivalotuksia.

Esimerkiksi "kuulluksi tulemisen" voi ajatella liittyvän keskeisellä tavalla kuulumisen tunteen kehittymiseen, ja vastaavasti ulkopuolisuuden kokemuksiin. Yhteiskunnassa marginalisoidut ryhmät, kuten nuoret (miehet, erityisesti muslimit) monissa Euroopan maissa, ovat joutuneet etsimään tahoja, jotka ovat heistä kiinnostuneita ja joissa heitä pidetään arvokkaina. Tämä on johtanut tilanteeseen, jossa osa nuorista on ajautunut radikaalien liikkeiden pariin.

Sosiaalitieteissä 2000-luvulla ahkerasti käytetty kuulumisen käsite on vähitellen saanut jalansijaa myös taiteiden tutkimuksen kentällä. Termi on nähty osittain rinnasteisena identiteetin käsitteelle. Kuuluminen, kuten identiteettikin, viittaa ihmisen kiinnittymisen, ja kiintymisen, kokemukseen; siihen, että jokin paikka tai yhteisö tuntuu kodilta, josta voi sanoa "kuulun tänne". Kuuluminen voi olla virallista, epämuodollista tai kuvitteellista. Ihminen voi olla esimerkiksi jonkin harrastusryhmän tai seuran tunnustettu jäsen. Toisaalta kyse voi olla enemmän subjektiivisesta tuntemuksesta; että kokee kuuluvansa esimerkiksi johonkin samoista asioista pitävien ihmisten joukkoon.

Kuulumisen merkitys ei kuitenkaan tyhjenny edellä mainittuihin, vaan se voidaan ymmärtää myös kuulumisen politiikkana, jonka tavoitteena voi olla esimerkiksi erilaisten ulos tai sisään sulkevien prosessien kyseenalaistaminen tai oikeuttaminen joko diskursiivisella tasolla tai käytännön toimien kautta 
(Antonsich 2010; Yuval-Davis 2006). Kuuluminen linkittyykin keskeisellä tavalla keskusteluun rajankäynneistä ja rajanvedoista: ketkä päästetään sisään, ketkä ei ja ketkä jättäytyvät vapaaehtoisesti ulos. Muurien pystyttäminen ja rajojen sulkeminen Euroopassa ovat esimerkkejä pyrkimyksistä rajata sitä, ketkä saavat kuulua eurooppalaisten joukkoon. Elokuvatutkimuksen yhteydessä aiheesta on kirjoittanut esimerkiksi Yosefa Loshitzky kirjassaan Screening Strangers: Migration and Diaspora in Contemporary European Cinema (2010).

Poikkikansallisessa maailmassa kiinnittymisen kohteet eivät ole yhtä itsestään selviä kuin kansallisessa järjestyksessä. Muuttoliikkeiden ${ }^{1}$ sekä kansallisvaltioiden merkityksen murenemisen myötä myös kansallisen kuulumisen reiteistä on tullut kompleksisempia kuin koskaan aiemmin. Kiinnittymisen muotoja ja paikkoja voi olla monia, ja ne voivat myös vaihdella eri elämäntilanteiden mukaan. Kuulumisen moniulotteiset kartat ovat siten täynnä sävyjä: niistä voi löytää kaipausta jotain todellista tai kuviteltua paikkaa tai yhteisöä kohtaan mutta myös kapinahenkeä ympäristön asettamia rajantekoja vastaan.

Viimeaikaisissa tutkimuksissa kuulumisen käsitteen avulla on pyritty kuvaamaan juuri tätä kiinnittymisten moninaisuutta ja muuntuvuutta suhteessa aikaan ja paikkaan: toisin sanoen kuulumisen prosessuaalista (Kannabiran \& al. 2006) tai performatiivista (Bell 1999) luonnetta. Tämänkaltaisten prosessuaalisten kokemusten, kuten kaipauksen, kuvaajana kuuluminen on haastanut identiteetin käsitteen, jonka on ymmärretty kuvaavan pysyvämpää tilaa - identifioitumisen prosessien "lopputulosta". Kuulumisen kysymystä on käsitelty enimmäkseen suhteessa marginaalisiin/marginalisoituihin ja tavalla tai toisella haavoittuvaisiin ryhmiin, kuten maahanmuuttajiin, seksuaalisiin vähemmistöihin, lapsiin, nuoriin ja vanhuksiin (Lähdesmäki \& al. 2016).

Edessäsi oleva Lähikuvan numero tarjoaa monta näkökulmaa siihen, miten kuulumisen kysymyksiä ja siihen läheisesti kietoutuvia teemoja on mahdollista tarkastella elokuvan ja audiovisuaalisen kulttuurin tutkimuksen parissa.

Kaksi numeron kolmesta tutkimusartikkelista käsittelee kuulumisen tematiikkaa maahanmuuton viitekehyksessä: ensimmäinen audiovisuaalisissa installaatioissa ja toinen ruotsalaisissa tyttöelokuvissa. Kolmas artikkeli nostaa esiin yhteiskuntaluokan merkityksen perheeseen kuulumisen kontekstissa suomalaisessa fiktioelokuvassa. Tarkasteltavana on niin virallisempia kuulumisen muotoja kuin subjektiivisempia kokemuksia.

Lehden artikkelit kuvaavat kuulumisesta käytävien neuvottelujen luomia jännitteitä yksilöiden, eri ryhmien ja yhteiskunnan välillä ja sisällä. Artikkelit kuvaavat myös suuntausta, joka on ollut nähtävissä audiovisuaalisen kulttuurin tutkimuksen parissa jo jonkin aikaa: nimittäin poikkitieteellisyyden nousua ja läheistä kanssakäymistä erityisesti kulttuurintutkimuksen ja yhteiskuntatieteellisen tutkimuksen kanssa.

Minna Rainio tutkii artikkelissaan maahanmuuton ja suomalaisuuden välisiä yhteyksiä sekä oman taiteellisen työnsä - liikkuvan kuvan installaatioiden - että tutkimuksensa kautta. Rainio pohtii, esimerkkinään hänen ja Mark Robertsin teos Maamme (2012), miten videoinstallaatio voi toimia siltana, rakentaa yhteyksiä, häivyttää rajoja ja tarjota pääsyn toisten kokemukseen eettisesti kestävällä tavalla. Hän kysyy, kenellä on lupa kuulua Suomeen ja miten kuulumista voidaan tuoda esiin videoinstallaation kautta.

Heta Mularin artikkelin materiaalina ovat ruotsalaiset tyttöelokuvat Lilja 4-ever (2002) ja Sano että rakastat minua (Säg att du älskar mig, 2005), jotka koskettavat maahanmuuton, seksuaalisuuden ja ihmiskaupan teemoja. Mulari tarkastelee elokuvissa esiintyvää itäeurooppalaista ja monikulttuurista tyttöyttä suhteessa ruotsalaiseen niin sanottuun tasa-arvotyttöyteen nostaen esiin
1 Maailmassa on tällä hetkellä noin 244 miljoonaa ihmistä, jotka asuvat synnyinmaansa ulkopuolella. Viimeisten 15 vuoden aikana siirtolaisten määrä on kasvanut noin 40 prosentilla. (YK 2015.) Toiset joutuvat jättämään kotinsa vastoin tahtoaan, ikävöiden aina takaisin. Toisille liikkuminen on etuoikeus, jännittävä mahdollisuus ja vapauden ilmentymä. 
myös aiheesta käydyt aikalaiskeskustelut. Hän tulkitsee elokuvia audiovisuaalisina kohtaamisina vieraiden tyttöyksien kanssa ja samalla avaa näiden kohtaamisten taustalla ollutta kulttuurihistoriallista tilannetta 1990-luvun alussa: Eurooppaa, jonka rajoja määriteltiin uudelleen.

Rainion ja Mularin artikkelit ilmentävät elokuvatutkimuksessa viime vuosina merkittäväksi suuntaukseksi noussutta transnationaalia lähestymistapaa. Transnationaali voidaan liittää esimerkiksi elokuvien sisällön, tuotannon, vastaanoton tai muodon tarkasteluun. Keskeistä on ollut kritisoida kansallisen elokuvatutkimuksen hegemoniaa maailmassa, jossa rajanteot ovat jatkuvassa liikkeessä niin konkreettisesti kuin kuvaannollisestikin (ks. esim. Higbee \& Lim 2010).

Kuten Elizabeth Ezra (Fisher \& Smith 2016) muistuttaa, samaan tapaan kuin kolonialismi on sisäänrakennettuna postkoloniaaliin, myös "poikkikansallinen" kantaa mukanaan jäänteitä kansallisesta järjestyksestä. Kansallisuuteen pohjautuva historiallinen narratiivi saa kuitenkin Rainion ja Mularin kuvaamissa elokuvissa rinnalleen poikkikansallisia kertomuksia, jotka kertovat esimerkiksi sosiaalisista epäoikeudenmukaisuuksista globaalilla tasolla.

Uusliberalistinen maailmanjärjestys on synnyttänyt yhteiskunnan fragmentoitumista uusilla tavoilla, ja sitä kautta yksilöissä irrallisuuden ja merkityksettömyyden kokemuksia, kun talouden vaikutukset ovat tunkeutuneet yksityiselämän piiriin. Nämä kysymykset nousevat esiin Tommi Römpötin artikkelissa. Hän analysoi kuulumista ja identiteetin määrittymistä perheen sisällä kotimaisessa elokuvassa Paha perhe (2010), jossa luokka nousee ratkaisevaksi määrittäjäksi perheeseen kuulumiselle. Römpötti tarkastelee rajojen pystyttämistä luokkien välille ihmisjätehuoltona.

Suomalaisessa kontekstissa luokkaeroja on pikemmin väheksytty kuin korostettu. Myös ideologiakriittisessä elokuvatutkimuksessa luokka on jäänyt usein vähemmälle huomiolle eroa luovana kategoriana kuin ikä, sukupuoli ja rotu, kuten Gerald Sim (2014) on huomauttanut.

Pinja Mustajoen katsausartikkelin aiheena on eläimen ja ihmisen suhde Robert Bressonin elokuvassa Balthazar (Au hasard Balthazar, Ranska 1966), jonka "päähenkilö" Balthazar-aasi kiertää omistajalta toiselle, ja suomalaisissa aktivistien kuvaamissa sikavideoissa, jotka kuvaavat tuotantoeläinten oloja. Posthumanismin viitekehyksessä Mustajoki pohtii eläimen ja ihmisen valtasuhdetta ja kysyy, mihin ja kenelle eläin kuuluu.

Toisessa katsausartikkelissa Kia Lindroos tarkastelee elokuvaa ajallisena todistajana esimerkkinään Chris Markerin dokumenttielokuva Patsaatkin kuolevat (Les statues meurent aussi, Ranska 1953), joka osallistui kolonialismin kritiikkiin kuvaamalla länsimaisiin museoihin suljettua ja samalla alkuperäisestä kontekstistaan ja merkityksistään irrotettua afrikkalaista taidetta. Lindroos kirjoittaa elokuvan roolista historian yksittäisten hetkien esiin nostajana ja siitä, miten nämä hetket tulevat osaksi laajempia visuaalisten todistusten verkostoja.

Tässä numerossa esitellyt audiovisuaaliset teokset (elokuvat ja videoinstallaatio) tuovat esiin kuulumisen moninaisia reittejä ja kuulumiseen liittyviä kysymyksiä niin ihmisten, eläinten kuin esineidenkin näkökulmasta. Odotamme mielenkiinnolla, miten kuulumisen käsite lähtee elämään ja millaisia muotoja se saa esimerkiksi posthumanistisen elokuvatutkimuksen kentällä.

Numeroon sisältyy myös kaksi erikoisherkkua: dokumenttielokuvantekijä ja -tutkija Jouko Aaltosen (s. 1956) tuore haastattelu sekä arkistoaarre vuodelta 1987, Kimmo Laineen ja Hannu Salmen "Elokuva yhteiskunnassa. Viisi ohjaajahaastattelua", jossa keskustellaan Matti Kassilan (s. 1924), Ere Kokkosen 
(1938-2008), Maunu Kurkvaaran (s. 1926), Rauni Mollbergin (1929-2007) ja Lauri Törhösen (s. 1947) kanssa. Nosto aloittaa Lähikuvassa uuden sarjan, "Arkistojen aarteet", jossa julkaistaan numeron teemaan tai henkeen sopivia artikkeleita menneiden vuosien numeroista. Palsta ennakoi myös ensi vuotta, jolloin lehti täyttää ansiokkaat 30 vuotta. Vaikka Lähikuva aloitti jo 1960-luvulla Turun elokuvakerhon lehtenä, oli 1987 ensimmäinen vuosi, jolloin lehdessä alettiin julkaista tieteellisiä artikkeleita. Laineen ja Salmen toteuttamat ohjaajahaastattelut ilmestyivät lehdessä, jonka pääkirjoitus alkaakin sanoin:

Syksy 1987 merkitsee Lähikuvalle suurta muodonmuutosta. Tästä numerosta lähtien lehdellä on kolme julkaisijaa: Suomen Elokuvatutkimuksen Seura, Turun Elokuvakerho ry. ja Varsinais-Suomen Elokuvakeskus ry. Muutos ei ole vain muodollinen vaan myös sisällöllinen: pyrkimyksemme on muokata Lähikuvasta valtakunnallisestikin merkittävä kanava suomalaiselle elokuvatutkimukselle. Tarkasti ottaen Lähikuva pyrkii nostamaan esille koko audiovisuaalisen kulttuurin rajaamatta ulkopuolelle televisiota ja videota niin kuin perinteinen elokuvatutkimus on usein tehnyt. (Lähikuva 4/1987.)

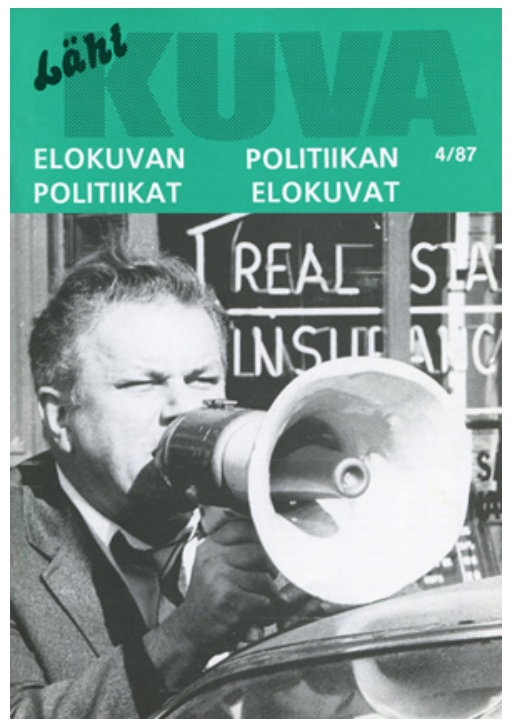

Lähikuvan muodonmuutokset ovat jatkuneet läpi sen 30-vuotisen historian, ja lehden aihepiiri on jatkanut laajentumistaan. Millaisia aiheita Lähikuvan sivuilla mahdetaan esitellä 30 vuoden päästä?

Jyväskylässä ja Turussa, joulukuussa 2016

Kaisa Hiltunen ja Niina Oisalo

\section{Lähteet}

Antonsich, Marco (2010) "Searching for Belonging - an Analytical Framework". Geography Compass vol. 4:6, 644-659.

Bell, Vikki (1999) “Performativity and Belonging. An Introduction”. Theory, Culture E Society vol. 16:2, 1-10.

Fisher, Austin \& Smith, Iain Robert (2016) "Transnational Cinemas: A Critical Roundtable". Frames Cinema Journal, no 9, huhtikuu 2016, <http://framescinemajournal.com/article/transnational-cinemas-a-critical-roundtable/>.

Higbee, Will \& Lim, Song Hwee (2010) “Concepts of Transnational Cinema: Towards a Critical Transnationalism in Film Studies". Transnational Cinemas, vol: 1:1, 7-21.

Kannabiran \& al. (2006) The Situated Politics of Belonging. Lontoo: Sage.

Loshitzky, Yosefa (2010) Screening Strangers: Migration and Diaspora in Contemporary European Cinema. Bloomington \& Indiana: Indiana University Press.

Lähdesmäki \& al. (2016) "Fluidity and Flexibility of 'Belonging': Uses of the Concept in Contemporary Research". Acta Sociologica vol. 59: 3, 233-247. 
Sim, Gerald (2014) The Subject of Film and Race. Retheorizing Politics, Ideology and Cinema. New York: Bloomsbury.

YK (2015) “Trends in international migration, 2015". Joulukuu 2015, United Nations Department of Economic and Social Affairs, Population Division, <http://www.un.org/en/development/ desa/population/migration/publications/populationfacts/docs/MigrationPopFacts20154.pdf >. Yuval-Davis, Nira (2006) "Belonging and the Politics of Belonging". Patterns of Prejudice vol. 40:3, 197-214. 